\title{
Efektivitas Distribusi Bantuan Keuangan Khusus Pada Masa Pandemi COVID-19 Di Kelurahan Simpang Baru
}

\author{
${ }^{1}$ Imanda Meylana, ${ }^{2}$ Abdul Sadad \\ ${ }^{1}$ Universitas Riau; imandameylana@ymail.com \\ ${ }^{2}$ Universitas Riau; abdulsadad78@yahoo.com
}

\begin{abstract}
In early 2020, COVID-19 has become a global health problem. At this time all groups of people are experiencing the economic impact of COVID-19, but considering that most of them are workers in the informal sector, they are very dependent on the community, so that the lower middle-class families suffer. The government responded to this condition by issuing a protection policy for families from the lower middle class who were affected by COVID-19, one of which was financial aid or BKK. Simpang Baru Village has also received an assignment from the City Government to distribute social assistance during the COVID-19 pandemic. However, after the distribution of BKK, it turns out that there are still many BKK that have not been distributed. The purpose of this study was to determine the effectiveness of the implementation of the Special Financial Assistance program throughout the time of the COVID-19 pandemic in Simpang Baru Village and identify factors that hindered the implementation of the BKK program. To achieve this goal, this research uses interactive analysis techniques with qualitative research types using the theory of program implementation effectiveness. This research shows that first, the effectiveness of the implementation of the BKK throughout the COVID-19 pandemic in Simpang Baru Village from four indicators, namely the percision of targets, the program socialisation process, the purpose of the program, and the program surveilling hasn't been effective. Second, the prohibiting factor is the comprehensiveness of the recipient data and socialisation from the implementing actor which are not implemented.
\end{abstract}

Keywords: Effectiveness of program implementation, BKK, Financial Aid Distribution.

\section{Pendahuluan}

Munculnya COVID-19 diawal tahun 2020 menjadi sebuah bencana bagi seluruh individu diseluruh dunia bahkan di Indonesia. Pada masa ini semua golongan masyarakat mengalami dan merasakan dampaknya, terlebih lagi pada bidang ekonomi, mengingat sebagian besar dari mereka adalah pekerja di sektor informal, mereka sangat bergantung pada pendapatan harian, sehingga keluarga kelas menengah ke bawah menderita. Dampaknya jauh lebih besar bahkan sampai kehilangan mata pencaharian mereka sehari-hari. Pemerintah Indonesia telah melakukan berbagai upaya untuk meminimalisir jumlah kasus positif COVID-19, yaitu dengan menerapkan Physical Distancing, Work Form Home (WFH), penggantian kegiatan belajar mengajar dari tatap muka menjadi daring kepada seluruh tingkat pendidikan baik formal maupun non formal, Pembatasan Sosial Berskala Besar (PSBB) dan berbagai upaya lainnya.

Dengan adanya kebijakan kegiatan yang mengharuskan masyarakat untuk bekerja di rumah (Work from Home) hingga belajar di rumah telah menyebabkan penurunan perekonomian di sektor informal, yang berarti pendapatan kelompok berpenghasilan rendah dan menengah semakin menurun. Dibeberapa daerah telah diberlakukan kebijakan Pembatasan Sosial Skala Besar (PSBB) yang melarang kegiatan diluar kegiatan memenuhi kebutuhan dasar masyarakat. Hal ini berdampak pada banyaknya sektor usaha mikro yang harus dibekukan sementara sehingga menyebabkan para pekerja harus berhenti bekerja. Para pekerja kelas menengah ke bawah yang hidup di sektor informal tanpa penghasilan menyebabkan peningkatan angka kemiskinan di masyarakat, karena kelas menengah ke bawah memiliki jumlah keluarga yang banyak dan tidak dapat mencari nafkah untuk hidup sendiri. 
Penyaluran BKK dilaksanakan secara sekaligus atau bertahap dengan cara pemindah bukuan dari rekening kas umum daerah provinsi ke rekening kas Kabupaten/Kota. Penyaluran secara bertahap, disalurkan berdasarkan permintaan dari pemerintah Kabupaten/Kota dengan mengajukan permohonan bantuan yang dilengkapi dengan proposal pengajuan kepada Gubernur. Penyaluran tahap berikutnya dilakukan setelah pemerintah kabupaten/kota menyampaikan laporan realisasi dan bukti penerimaan bantuan yang ditandatangani oleh masing-masing penerima dan disahkan oleh Kepala Dinas Sosial Kabupaten/Kota. Dalam penyaluran kepada masyarakat penerima, pemerintah Kabupaten/Kota dapat menganggarkan biaya operasional yang bersumber dari anggaran pendapatan dan belanja daerah Kabupaten/Kota masing-masing. Berikut adalah gambaran mekanisme penyaluran BKK di kota Pekanbaru:

Gambar 1.

Mekanisme Penyaluran BKK

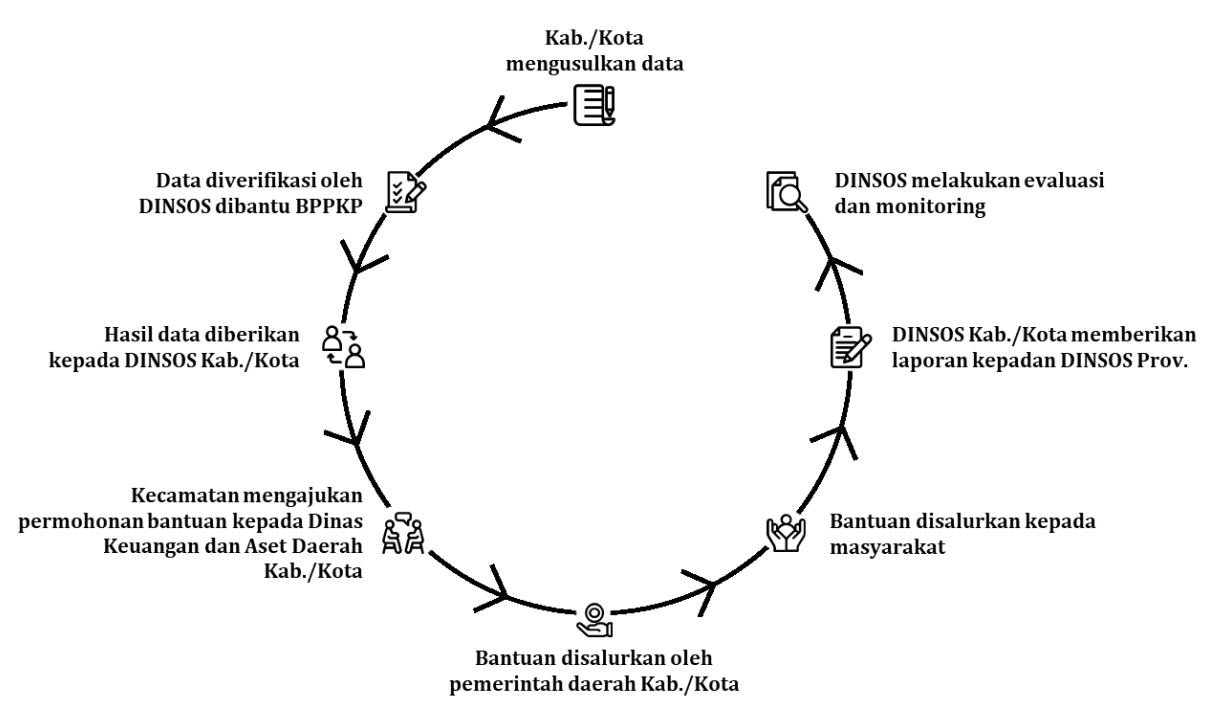

Sumber: Dinas Sosial Prov. Riau (2020)

Proses penyaluran Bantuan Keuangan (BKK) Khusus Provinsi Riau kepada masyarakat dapat diambil melalui Bank BPR Pekanbaru (pembukaan nomor rekening), Bank Riau Kepri (Virtual Account) dan Bank BRI (khusus Kecamatan Rumbai Pesisir) untuk tahap awal dibayarkan 1 bulan terlebih dahulu. Sebelumnya Dinas Sosial akan memberikan kepada Lurah surat pengantar data rekening Bank penerima BKK Provinsi Riau; rekomendasi asli penerima BKK Provinsi Riau untuk diserahkan kepada masyarakat; dan tanda terima surat pengantar dan rekomondasi asli penerima BKK disertai dengan dokumentasi. Bagi masyarakat yang mengambil rekomendasi ke Lurah harus membawa, fotokopi KK dan E-KTP, mengisi tanda terima, foto/dokumentasi serah terima surat rekomendasi dari pihak Kelurahan kepada yang bersangkutan. Kota Pekanbaru sendiri sudah menyaluran BKK sejak bulan mei sampai dengan juli 2020 untuk tahap I sedangkan untuk tahap II dimulai bulan desember sampai dengan februari 2021. Berikut ialah rekapitulasi penyaluran BKK di Kota Pekanbaru dalam setiap tahapnya: 
Tabel 1.

Alokasi dana BKK Provinsi Riau Tahun 2020

\begin{tabular}{|c|c|c|}
\hline No & Kabupaten/Kota & Alokasi Anggaran \\
\hline 1 & $\begin{array}{l}\text { Kota Pekanbaru } \\
\text { (300 Ribu Rupiah x } 29.662 \text { KK x } 3 \text { Bulan) }\end{array}$ & $26,695,800,000.00$ \\
\hline 2 & $\begin{array}{l}\text { Kabupaten Kampar } \\
\text { (300 Ribu Rupiah x } 6.920 \text { KK x } 3 \text { Bulan) }\end{array}$ & $6,228,000,000.00$ \\
\hline 3 & $\begin{array}{l}\text { Kabupaten Bengkalis } \\
\text { (300 Ribu Rupiah x } 22.684 \text { KK x } 3 \text { Bulan) }\end{array}$ & $20,415,600,000.00$ \\
\hline 4 & $\begin{array}{l}\text { Kabupaten Indragiri Hulu } \\
\text { (300 Ribu Rupiah x } 20.380 \text { KK x } 3 \text { Bulan) }\end{array}$ & $18,342,000,000.00$ \\
\hline 5 & $\begin{array}{l}\text { Kabupaten Indragiri Hilir } \\
\text { (300 Ribu Rupiah x } 14.428 \text { KK x } 3 \text { Bulan) }\end{array}$ & $12,985,200,000.00$ \\
\hline 6 & $\begin{array}{l}\text { Kabupaten Kuantan Singingi } \\
\text { (300 Ribu Rupiah x } 8.486 \text { KK x } 3 \text { Bulan) }\end{array}$ & $7,637,400,000.00$ \\
\hline 7 & $\begin{array}{l}\text { Kota Dumai } \\
\text { (300 Ribu Rupiah x } 32.795 \text { KK x } 3 \text { Bulan) }\end{array}$ & $29,515,500,000.00$ \\
\hline 8 & $\begin{array}{l}\text { Kabupaten Rokan Hulu } \\
\text { (300 Ribu Rupiah x } 8.714 \text { KK x } 3 \text { Bulan) }\end{array}$ & $7,842,600,000.00$ \\
\hline 9 & $\begin{array}{l}\text { Kabupaten Rokan Hilir } \\
\text { (300 Ribu Rupiah x } 32.942 \text { KK x } 3 \text { Bulan) }\end{array}$ & $29,647,800,000.00$ \\
\hline 10 & $\begin{array}{l}\text { Kabupaten Pelalawan } \\
\text { (300 Ribu Rupiah x } 6.498 \text { KK x } 3 \text { Bulan) }\end{array}$ & $5,848,200,000.00$ \\
\hline 11 & $\begin{array}{l}\text { Kabupaten Siak } \\
\text { (300 Ribu Rupiah x 18.034 KK x } 3 \text { Bulan) }\end{array}$ & $16,230,600,000.00$ \\
\hline 12 & $\begin{array}{l}\text { Kabupaten Kepulauan Meranti } \\
\text { (300 Ribu Rupiah x 11.350 KK x } 3 \text { Bulan) }\end{array}$ & $10,215,000,000.00$ \\
\hline & Total & $191,603,700,000.00$ \\
\hline
\end{tabular}

Sumber: Pemerintah Provinsi Riau (2020)

Dengan adanya kebijakan dan kondisi tersebut, pemerintah pun merenspon dengan mengeluarkan kebijakan perlindungan bagi seluruh masyarakat yang telah terdampak COVID19, yaitu berbagai macam bantuan sosial maupun finansial. Program bantuan sosial merupakan salah satu komponen program jaminan sosial yang menjadi bentuk realisasi tanggung jawab pemerintah atau pemerintah daerah yang sangat peduli terhadap kondisi masyarakat bawah. Untuk pemerintah Provinsi Riau sendiri mengadakan bantuan salah satunya adalah bantuan keuangan untuk penduduk di Kota Pekanbaru yaitu Bantuan Keuangan yang bersifat Khusus (BKK) yang berjumlah besaran Rp 300.000 perbulannya selama 3 bulan. BKK ini bertujuan sebagai penunjang ekonomi seluruh masyarakat yang terdampak COVID-19 dan tidak termasuk pada data penerima bantuan lain, baik bantuan sosial maupun bantuan tunai. BKK yang merupakan program dari Provinsi Riau merupakan bantuan yang dianggarkan dengan anggaran APBD Provinsi Riau tahun anggaran 2020. Provinsi Riau mengalokasikan dana BKK untuk seluruh kabupaten/kota sebesar 191,6 miliar rupiah, untuk 212.893 KK dan di Kota Pekanbaru sendiri mendapat alokasi dana sebanyak 26,6 miliar untuk $26.662 \mathrm{KK}$. 
Tabel 2.

Rekapitulasi penyaluran BKK Di Kecamatan Tampan

\begin{tabular}{ccccccc}
\hline \multirow{2}{*}{ Kelurahan } & \multicolumn{3}{c}{ Tahap 1 } & \multicolumn{3}{c}{ Tahap 2 } \\
\cline { 2 - 7 } & Salur & Tidak Salur & Total & Salur & Tidak Salur & Total \\
\hline Air Putih & 305 & 157 & 462 & 151 & 214 & 365 \\
\hline Binawidya & 246 & 138 & 384 & 145 & 130 & 275 \\
\hline Delima & 230 & 141 & 372 & 167 & 63 & 230 \\
\hline Sialang Munggu & 328 & 225 & 570 & 250 & 215 & 465 \\
\hline Sidomulyo Barat & 611 & 648 & 1.258 & 507 & 265 & 772 \\
\hline Simpang Baru & $\mathbf{1 9 3}$ & $\mathbf{2 3 5}$ & $\mathbf{4 2 8}$ & $\mathbf{1 6 6}$ & $\mathbf{1 2 0}$ & $\mathbf{2 8 6}$ \\
\hline Tobek Godang & 255 & 117 & 372 & 181 & 84 & 265 \\
\hline Tuah Karya & 323 & 257 & 579 & 211 & 103 & 314 \\
\hline Tuah Madani & 276 & 97 & 374 & 217 & 123 & 340 \\
\hline TOTAL & $\mathbf{2 . 7 6 7}$ & $\mathbf{2 . 0 1 5}$ & $\mathbf{4 . 7 9 9}$ & $\mathbf{1 . 9 9 5}$ & $\mathbf{1 . 3 1 7}$ & $\mathbf{3 . 3 1 2}$ \\
\hline \multicolumn{7}{c}{ Sumber: Dinas Sosial Kota Pekanbaru, 2021. }
\end{tabular}

Di kelurahan Simpang Baru sendiri tercatat ada sebanyak 428 KK pada tahap 1 dan 286 KK pada tahap 2 yang mendapatkan bantuan tersebut. Bantuan ini telah disalurkan kepada masyarakat yang tercatat, namun ternyata masih banyak masyarakat yang terhambat penerimaannya dengan berbagai penyebab seperti tidak lengkapnya data dan terhalang oleh ketidaktahuan masyarakat yang merupakan akibat dari tidak berjalannya sosialiasi, sehingga forum RT/RW langsung menuju ke kantor Kelurahan Simpang Baru untuk menanyai kejelasan tersebut. Selain itu, sangat tertutupnya aparat kelurahan yang tidak bisa memberi informasi lebih lengkap membuat peniliti kesusahan untuk mendapatkan kejelasan dari proses penyaluran bantuan yang ada di Kelurahan tersebut. Ini seperti membuktikan bahwa sepertinya Kelurahan Simpang Baru sepertinya tidak mampu menjalankan tugasnya dalam melaksanakan pendistribusian BKK.

Efektivitas menurut Mardiasmo dalam Chandra (2020) merupakan sebuah ukuan dalam pencapaian tujuan sebuah program atau tujuan. Jika sebuah organisasi atau lembaga mampu mencapai tujuannya maka dapat dikatakan efektif, begitu pula sebaliknya, jika orgnisasi tidak mampu mencapai tujuannya maka tidak efektif. Indikator dari penggambaran efektivitas adalah bentuk dari dampak yang dihasilkan pada sebuah program. Apabila dampak yang dihasilkan semakin besar terhadap sasaran yang yang telah ditentukan, maka semakin efektif sebuah organisasi dalam melaksanakan programnya. Sedangkan menurut Zakiyah dkk, efektivitas merupakan sebuah ukuran dalam menggambarkan pencapaian target sebuah program. Indikatorindikator yang dapat menentukan kefektivitasan ini ialah ketepatan penentuan pilihan, waktu, tujuan dan sasaran (2020). Menurut Komaruddin dalam Maun (2020) menjelaskan bahwa efektivitas merupakan sebuah situasi yang menunjukkan tingkat keberhasilan sebuah program atau kegiatan yang sebelumnya telah direncanakan. Menurut Khadafi \& Mutiarin, keterkaitan efektivitas dengan BKK adalah dengan mengukur indikator keberhasilan pelaksanaan program BKK yaitu tepat sasaran penerima manfaat, tepat jumlah, tepat waktu, tepat administrasi, dan tepat penggunaanya (2017).

Pada penelitian ini peneliti menggunakan teori ukuran efektivitas dari Budiani (2017). Penelitian dilaksanakan dengan melakukan wawancara terhadap para aktor yang terlibat, mereduksi data yang didapat peneliti dari sumber yang terpercaya, serta menyajikan data-data yang dibutuhkan untuk memperjelas penggambaran permasalahan dalam penelitian ini. Adapun indikator pelaksanaan program penyaluran BKK adalah: 
1) Ketepatan Sasaran Program.

Pemahaman program dalam hal ini sejauh mana peserta program tepat dengan sasaran yang sudah ditentukan sebelumnya. Maka dalam penelitian ini melihat bagaimana para aktor yang terlibat dalam penyaluran BKK dapat menargetkan kepada sasaran penyaluran yang tepat.

2) Sosialisasi Program.

Dalam hal ini, sosialisasi program dapat dikaitkan dengan sejauh mana pemangku kepentingan atau kelompok pemangku kepentingan lainnya mengetahui, memahami, dan memberikan proses pemahaman kepada masyarakat terkait program BKK ini. Maka dalam penelitian ini melihat sosialisasi yang dapat dilakukan aktor yang terlibat dalam memberikan pemahaman kepada KPM BKK, dan KPM BKK dapat mengerti dan memahami dengan baik mengenai program dan prosedur penyaluran BKK.

3) Tujuan Program.

Bagaimana sebuah program sudah berjalan sesuai dengan tujuan yang tertulis mau pun tidak tertulis. Sehingga keefektifan suatu program dapat diukur dengan tujuan yang sudah ada. Maka dalam penelitian ini menjelaskan hasil dari penyaluran BKK dapat membantu masayarakat di Kota Pekanbaru, khususnya masyarakat di Kelurahan Simpang Baru

4) Pemantauan program.

Merupakan aktivitas atau kegiatan yang dilaksanakan setelah program berjalan. Pemantuan program merupakan bentuk evaluasi, sejauh mana program memberikan dampak bagi masyarakat peserta program serta pelaksanaan program harus sesuai dengan waktu dan tujuannya. Maka dalam penelitian ini menjelaskan penyaluran BKK yang telah dilaksanakan oleh para aktor yang terlibat dengan baik dan tepat sesuai dengan prosedur yang ada (JUKNIS).

Tujuan dari penelitian ini adalah untuk mengetahui tingkat efektivitas penyaluran BK pada masa pandemi COVID-19 bagi masyarakat yang terkena dampak COVID-19 di Kelurahan Simpang Baru dan mengetahui apa saja faktor penghambat dalam pelaksanaan penyaluran BKK di Kelurahan Simpang Baru pada masa pandemi COVID-19.

\section{Metode Penelitian}

Penelitian ini bertujuan untuk melihat efektivitas distribudi BKK pada masa pandemi COVID-19 di Kelurahan Simpang Baru, Kecamatan Tampan. Tipe penelitian yang digunakan dalam penelitian ini adalah metode penelitian deskriptif melalui pendekatan metode penelitian kualitatif. Melalui pendekatan deskriptif yang digunakan pada penelitian ini penulis akan memperoleh gambaran yang lengkap dari permasalahan yang dirumuskan dengan memfokuskan pada proses pencarian dari setiap data yang ada di lapangan. Dengan harapan agar informasi yang dikaji lebih bersifat mendalam, alamiah dan rasional. Alasan peneliti menggunakan jenis dan pendekatan penelitian ini adalah menimbang dari sumber data yang dihasilkan peneliti. Sumber data pada penelitian ini adalah sebagai berikut :

1. Sumber data primer pada penelitian ini ialah hasil dari wawancara dengan:

- Kepala Seksi Penanganan Fakir Miskin di DINSOS Provinsi Riau.

- Penanggung jawab program BKK dari seksi Penanganan Fakir Miskin di DINSOS Kota Pekanbaru. 
- Lurah Simpang Baru merupakan orang pertama yang akan diberi wewenang mengenai BKK.

- Kasi Kesejahteraan Sosial dan Pemberdayaan Masyarakat di Kelurahan Simpang Baru.

- RT yang ada di Kelurahan Simpang Baru.

- KPM BKK di Kelurahan Simpang Baru.

2. Sumber data skunder pada penelitian ini didapatkan dari berbagai sumber yaitu :

- Pergub No. 29 Tahun 2020

- SK dan JUKNIS Bantuan Keuangan Khusus COVID-19.

- Keputusan Gubernur Riau No. kpts.848/V/2020 mengenai Alokasi dana BKK seProvinsi Riau,

- Data Alokasi dana BKK se-Provinsi Riau

- Data jumlah penerima BKK se-Provinsi Riau.

- Data jumlah penerima BKK se-Kota Pekanbaru.

- Data penyaluran BKK Kecamatan Tampan

Teknik pengumpulan data yang digunakan dalam penelitian ini ialah dengan berbagai cara yaitu, observasi, wawancara dan dokumentasi. Jika semua data yang dibutuhkan sudah lengkap dan terkumpul, maka data tersebut akan dianalisis untuk menjadi pembahasan. Teknik analisis data yang digunakan dalam penelitian ini adalah kualitatif dengan menggunakan model interaktif dimana data yang diperoleh dari subjek penelitian ditemukan, diolah sesuai dengan teori yang digunakan yaitu efektivitas dan dikonfirmasi oleh pendapat yang kompeten dari orang yang diamati, lalu akan dijelaskan dan digambarkan. Kesimpulan dan saran berdasarkan penjelasan ini, membantu menyelesaikan masalah terkait dengan rumusan masalah.

\section{Hasil dan Pembahasan}

Berdasarkan tabel 2 diatas, dijelaskan bahwa pada tahap pertama sebanyak 193 KPM dan tidak tersalurkan $235 \mathrm{KPM}$ dengan total 428, kemudian pada tahap kedua berkurang menjadi 166 KPM dan tidak tersalurkan sebanyak 120 KPM. Pada tahap pertama banyak yang tidak menerima dikarenakan banyak yang tidak mengetahui bagaimana proses pengambilan BKK. Sedangkan pada tahap kedua jumlah yang disalurkan berkurang karena pada tahap sebelumnya tidak ada pelaporan evaluasi oleh Dinas sosial Kota Pekanbaru kepada Dinas sosial Provinsi Riau. Pembahasan mengenai efektivitas pelaksanaan program BKK dibagi menjadi dua bagian yaitu bagian pertama, pembahasan mengenai indikator- indikator penentu efektivitas distribusi BKK. Bagian kedua, dibahas mengenai hambatan-hambatan yang muncul muncul pelaksanaan program tersebut beserta upaya pemecahannya. Secara lebih jelas pembahasan tentang efektivitas distribusi BKK di Kelurahan Simpang Baru tersebut dapat dilihat pada pembahasan berikut ini:

\section{Efektivitas Distribusi Bantuan Keuangan (BKK) Khusus pada MasaPandemi COVID-19 di Kelurahan Simpang Baru.}

\section{Ketepatan Sasaran}

Ketepatan sasaran program yaitu dimana peserta program tepat dengan sasaran yang sudah ditentukan sebelumnya sehingg dapat mencapai tujuan program. Untuk melihat dan 
menganalisa ketepatan sasaran program maka indikatornya ditujukan kepada masyarakat penerima yaitu Keluarga Penerima Manfaat (KPM). Dengan ketepatan sasaran yang efektif maka tujuan dari program akan tercapai dengan mudah. Pada bagian ini kesesuaian antara tujuan dari program dengan sasaran program akan diukur. Hal ini sesuai dengan Peraturan Gubernur No.29 Tahun 2020 Tentang Penganggaran dan Petunjuk Teknis Penyaluran BKK Dalam Penanganan Dampak COVID-19.

Ketepatan sasaran dalam seleksi KPM dapat mencapai tujuan pendistribusian BKK. Pada bagian ini akan mengukur bagaimana kesesuaian tujuan program terhadap kelompok sasaran atau KPM. Pada proses penunjukkan sasaran KPM BKK didapatkan dari data non-DTKS yaitu masyarakat yang belum mendapatkan bansos dalam bentuk apapun. Selain dari data tersebut Dinas sosial juga mendapatkan data dari laporan kelurahan maupun RT/RW, namun begitupun masih banyak yang tidak bisa menerima, adanya masyarakat yang tidak bisa menerima bantuan ialah adanya NIK yang tidak valid sehingga Dinas sosial tidak bisa memberikan bantuan kepada nama yang tidak memiliki NIK yang valid. Hal terpenting dalam pelaksanaan prorgram BKK yaitu dengan memiliki data yang valid, sehingga masyarakat yang tepat dan sesuai dengan tujuan program dapat menerima bantuan-bantuan selama masa pandemi, untuk menghindari kendalakendala yang mungkin dapat terjadi diluar ketentuan dan pentunjuk teknis yang ada. Dalam hal ini masih banyak kendala yang terdapat, diketahui bahwa ketepatan sasaran penyaluran BKK belum sepenuhnya dengan petunjuk teknis yang ada, yaitu masih adanya nama yang tertulis dua kali atau ada NIK yang tidak valid.

\section{Sosialisasi Program}

Dalam melaksanakan sebuah program, pertama-tama peserta program harus dikenalkan kepada program yang akan mereka laksankan, kegiatan pengenalan tersebut disebut dengan sosialisasi. Pada kegiatan ini, masyarakat disosialisasikan tentang program BKK di masa pandemi COVID-19. Proses ini merupakan proses terpenting dalam pelaksanaan program, karena masyarakat dapat memahami apa tujuan program dari sosialisasi ini. Sejauh mana pengetahuan masyarakat akan program BKK akan diukur pada aspek ini. Maka dari hasil penelitian yang telah dilakukan, dapat diketahui sosialisasi mengenai penyaluran BKK tidak dilaksanakan sepenuhnya oleh pihak keluraha, begitu juga dengan pihak Dinas sosial Kota Pekanbaru maupun Dinas sosial Provinsi Riau. Selain itu hanya para ketua RT/RW yang telah melaksanakan sosialisasi dengan kepada masyarakat dengan mendatangi beberapa penerima untuk menjelaskan proes penerimaan BKK. Berdasarkan pada analisis wawancara diatas aspek sosialisasi program dapat dikatakan tidak efektif, karena sosialisasi tidak dilaksanakan sepenuhnya oleh para-para aktor yang ada, padahal dapat kita ketahui sosialiasi merupakan proses yang penting dalam pelaksanaan sebuah program, karena bagaimana masyarakat bisa mengerti akan program yang ada apabila sosialisasinya tidak dilaksanakan.

\section{Tujuan Porgram}

Tujuan program ialah, sejauh mana kesesuaian antara hasil pelaksanaan program dengan tujuan yang telah di tetapkan sebelumnya. Tujuan dari program BKK sendiri ialah untuk meingkatkan perekonomian masyarakat pada masa pandemi COVID-19. Sudah atau belum sesuainya pelaksanaan program dengan tujuan program akan diketahui pada indikator ini.

Berdasarakan dari hasil penelitian yang didapat diketahui bahwa tujuan dari diadakannya program BKK adalah untuk membantu menunjang perekonomian seluruh masyarakat yang telah terdampak COVID-19 yang belum mendapatkan jenis bantuan sosial apapun dan ternyata hasilnya belum tercapai. Masih ada masyarakat yang merasa kurang dengan jumlah BKK yang diberikan karena jumlah tiga ratus ribu perbulan itu dirasa tidak cukup bagi seorang apalagi satu keluarga, masyarakat menyatakan bahwa kebutuhan mereka semakin banyak dan pendapatan mereka semakin sedikit karena COVID-19. Berdasar pada hasil analisa tersebut pada tujuan 
program belum efektif dikarenakan adanya ketidakpuasan yang masyarakat rasakan dengan nominal yang diberikan oleh pemerintah.

\section{Pemantauan Program}

Pemantauan program merupakan kegiatan yang dikerjakan setelah penyaluran BKK untuk memberitahukan kepada masyarakat bahwa BKK adalah bentuk dari kepedulian pemerintah kepada masyarakat dalam penanganan COVID-19. Pemantauan juga merupakan kegiatan untuk memantau kemajuan pelaksanaan program, mengidentifikasi dan memprediksi masalah, dan mengambil tindakan sesegera mungkin. Sehingga hal yang dapat diketahui dari penelitian bahwa pemantauan dari program BKK sudah belum efektif karena, masih adanya pihak yang tidak memastikan apakah penyaluran BKK telah tersalurkan kepada masyarakat di Kelurahan Simpang Baru secara langsung atau tidak.

Pemantauan pelaksanaan program BKK, dari DINSOS Prov. Riau secara langsung memang tidak dilakukan, tetapi diganti dengan dilaksanakannya rapat koordinasi bersama dengan perwakilan-perwakilan dari setiap kabupaten atau kota di provinsi riau, untuk membahas mengenai pelaksanaan atau penyaluran BKK, pemantauan yang dimaksud ialah dengan monitoring dan evaluasi. Monitoring yaitu diadakannya rapat koordinasi seperti yang dijelaskan diatas. Selain itu untuk bahan evaluasi dinas porvinsi menggunakan pedoman dari laporanlaporan yang telah dikumpulkan oleh dinas sosial kabupaten atau kota diseluruh Provinsi Riau. Apabila laporan tersebut tidak dikumpulkan maka Dinas sosial Provinsi Riau tidak akan memberikan bantuan ditahap berikutnya. Pemantauan dibutuhkan untuk mengevaluasi hasil dari pelaksanaan program BKK. Sedangkan pemantauan pelaksanaan penyaluran BKK tidak dilaksanakan oleh pihak kelurahan, melainkan dilakukakan oleh pihak bank secara langsung. Berdasarkan pada penjelasan, bahwa memang pihak kelurahan sama sekali tidak ikut andil atau melaksanakan pemantauan, dari hal ini bisa disimpulkan bahwa pihak kelurahan tidak mengetahui apakah BKK benar-benar telah sampai ke masyarakat di Kelurahan Simpang Baru secara langung atau tidak. Maka dari itu pemantauan pelaksanaan program BKK belum efektif karena adanya ketidakpahaman mengenai makna dari pemantauan.

\section{Faktor Penghambat Efektivitas Penyaluran BKK Pada Masa Pandemi COVID-19 Di Kelurahan Simpang Baru}

Tidak bisa kita pungkiri bahwa setiap pelaksanaan dalam menyelenggarakan suatu program pasti selalu ada hal-hal penghambat yang terjadi didalam pelaksanaannya. Untuk mencapai keinginan yang diharapkan dalam menjalankan suatu program tidaklah mudah meskipun segala urusan tersebut dilakukan secara maksimal. Ditambah lagi dengan sistem pemerintahan di Indonesia dimana setiap pelaksanaan dilakukan dari meja ke meja sehingga banyak aktor yang terjun dalam pelaksanaan tersebut. Untuk mencapai hasil yang memuaskan tidak terlepas dari hambatan-hambatan maupun kendala-kendala yang disebabkan oleh beberapa faktor yang berbeda begitu juga dengan pelaksanaan penyaluran BKK di Kelurahan Simpang Baru, Kecamatan Bina Widya, Kota Pekanbaru. Jika faktor yang menjadi kendala dalam pelaksanaannya tidak dapat diatasi maka akan berdampak pada kegagalan pencapaian tujuan program dan apabila sebuah program sudah gagal dari tujuannya maka tingkt kefektivitasan program tersebut akan berkurang.

\section{Kelengkapan Data}

Data merupakan hal yang terpenting pertama dalam setiap pelaksanaan program, pasalnya program dapat berjalan secara sesuai dan tepat sasaran apabila data yang dimiliki oleh penyelanggara program sudah benar dan terpercaya. Penyaluran bantuan dapat berjalan dengan baik apabila sasaran yang ditentukan sudah jelas, begitu pula dengan kelengkapan data setiap 
sasaran, maka dari itu dalam hal ini NIK adalah hal terpenting pada saat pelaksanaan penyaluran bantuan seperti pada masa ini, karena agar masyarakat dapat menerima BKK ini, maka NIK mereka haruslah valid. Dengan adanya ketidaklengkapan data ini menjadi permasalahan serta penghambat dalam pelaksanaan program BKK ini sebabnya tidak validnya beberapa NIK dari masyarakat mengakibatkan tidak terbagi atau tersalurnya bantuan secara merata kepada para sasaran, karena ada beberapa sasaran yang datanya tidak valid sehingga bantuan BKK tidak dapat dibagikan kepada orang yang bersangkutan.

\section{Komunikasi Antar Organisasi}

Faktor penghambat yang kedua adalah komunikasi antar organisasi tidak efektif, dari Dinas Sosial Provinsi Riau bahwa tidak adanya konfirmasi lanjutan mengenai penyaluran BKK pertahapan yang dilaporkan untuk bahan evaluasi. Sedangkan dari pihak RT di Kelurahan Simpang Baru, mengaku bahwa pihak Kelurahan Simpang Baru tidak pernah memberikan keterangan lebih lanjut mengenai data penerima penyaluran BKK. Hal ini tentunya menjadi salah satu penghambat dalam keefektifan penyaluran BKK pada masa pandemi COVID-19 di Kelurahan Simpang Baru. Pada masa pandemi COVID-19 dengan adanya BKK diharapkan dapat membantu masyarakat yang terdampak untuk memenuhi kebutuhan sehari- harinya. Tetapi dalam proses penyalurannya kepada masyrakat terdapat dua faktor penghambat yaitu adanya data masyarakat yang tidak lengkap dan komunikasi antar organisasi yang tidak efektif. Seharusnya faktor pengahambat ini dapat diminimalisir agar penyaluran BKK dapat terlaksana dengan baik dan efektif.

\section{Simpulan}

Berdasarkan pada hasil dan pembahasan yang telah dijelaskan sebelumnya, mengenai efektivitas pelaksanaan penyaluran BKK pada masa pandemi COVID-19 di Kelurahan Simpang Baru. Adapun jumlah bantuan yang dibagikan untuk Kelurahan Simpang Baru sebanyak 193 KPM dan tidak tersalurkan 235 KPM dengan total 428, kemudian pada tahap kedua berkurang menjadi 166 KPM dan tidak tersalurkan sebanyak 120 KPM. Efektivitas dari pelaksanaan penyaluran BKK diukur dengan 4 indikator efektivitas yaitu: Pertama, ketepatan sasaran, dapat diketahui bahwa ketepatan sasaran penyaluran BKK sesuai dengan petunjuk teknis yang telah ditentukan dari pemerintahan pusat yaitu Kemensos. Namun masih ada bantuan yang tidak tersalurkan, salah satu faktornya ialah karena adanya NIK yang tidak valid dari beberapa nama penerima manfaat BKK. Sehingga pada ketepatan sasaran belum bisa dikatakan efektif; Kedua, sosialisasi program yang tidak dilaksanakan oleh para aktor pelaksana BKK baik dari DINSOS hingga pihak kelurahan. Namun hanya para ketua RT/RW yang telah melaksanakan sosialisasi dengan kepada masyarakat dengan mendatangi beberapa penerima untuk menjelaskan proes penerimaan BKK. Sehingga pada aspek sosialisasi program dapat dikatakan tidak efektif; Ketiga, tujuan program BKK ialah untuk membantu masyarakat yang terdampak COVID-19 dengan bantuan dana jumlah Rp. 300.000. Tetapi masyarakat merasa bahwa dengan jumlah 300 ribu masyakarat belum terbantu, sehingga tidak sesuai dengan tujuan dari program BKK, sehingga tidak efektif bagi masyarakat; Keempat, pemantauan program yang tidak dilaksanakan secara maksimal oleh para aktor pelaksana program BKK.

Faktor-faktor penghambat efektivitas pelaksanaan penyaluran BKK bagi masyarakat yang terdampak COVID-19 di Kelurahan Simpang Baru, terdapat dua faktor penghambat yaitu : Pertama, faktor kelengkapan data yang dimiliki oleh beberapa KK yang terdapat di Kelurahan Simpang Baru; Kedua, penghambat juga terjadi karena tidak adanya komunikasi antar organisasi yang baik dalam proses pelaksanaan BKK pada masa pandemi COVID-19. Dengan adanya faktor penghambat tersebut dapat diketahui bahwa pihak kelurahan dan pihak Dinas sosial mempunyai alasan tersendiri mengenai pelaksanaan program BKK tersebut.semestinya dan lebih efektif. 


\section{Referensi}

Budiani, N. W. (2017). Efektivitas Program Penanggulangan Pengangguran Karang Taruna "Eka Taruna Bhakti" Desa Sumerta Kelod Kecamatan Denpasar Timur Kota Denpasar. Jurnal Ekonomi Dan Sosial (INPUT), 2(1), 49-57.

Chandra, C. A., Sabijono, H., \& Runtu, T. (2020). Efektivitas Dan Kontribusi Penerimaan Pajak Bumi Dan Bangunan Perdesaan Dan Perkotaan (Pbb-P2) Terhadap Penerimaan Pendapatan Asli Daerah (Pad) Di Kota Gorontalo Tahun 2016-2018. Going Concern: Jurnal Riset Akuntansi, 15(3), 290-298. https://doi.org/https://doi.org/10.32400/gc.15.3.28541.2020

Dinas Sosial Provinsi Riau. (2020). Keputusan Kepala Dinas Sosial Provinsi Riau No. kpts.39/V/2020 Tentang Petunjuk Teknis Bantuan Keuangan Khusus Kepada Kabupaten/Kota Dalam Rangka Penanganan Dampak Corona Virus Disease 2019 (COVID-19) Yang Bersumber Dari Anggaran Pendapatan Dan Belanja Daerah Provinsi Riau Tahun 2020. https://gugustugas.riau.go.id/suratkeputusan

Fernando, C. E. F. (2020). Efektivitas Bantuan Langsung Tunai Dana Desa Bagi Masyarakat Miskin Terkena Dampak Covid-19 Di Desa Talaitad Kecamatan Suluun Tareran Kabupaten Minahasa Selatan. Jurnal Politico, https://ejournal.unsrat.ac.id/index.php/politico/issue/view/2617

Keputusan Gubernur Riau Nomor 848/V/2020 Tentang Penetapan Alokasi Bantuan Keuangan Pemerintah Kabupaten/Kota Untuk Penanganan Dampak Sosial COVID-19 Yang Bersumber Dari APBD Provinsi Riau Tahun Anggaran 2020. (2020). https:/gugustugas.riau.go.id/suratkeputusan

Kettner, P. M., Moroney, R. M., \& Martin, L. L. (2008). DESIGNING AND MANAGING PROGRAMS: Vol. Third Edition (3rd ed.). SAGE Publications.

Khadafi, R., \& Mutiarin, D. (2017). Efektivitas Program Bantuan Keuangan Khusus Dalam Mengentaskan Kemiskinan di Kabupaten Gunungkidul. Journal of Governance and Public Policy, 4(2). https://doi.org/10.18196/jgpp.4280

Makmur(H.). (2011). Efektivitas kebijakan kelembagaan pengawasan. Refika Aditama.

Zakiyah, N., OKtavia, L., Khairiyah, F., \& Ilman, M. A. (2020). Efektivitas Pelaksanaan Bantuan Sosial Dari Pemerintah Terhadap Masyarakat Terdampak Covid-19 Di Desa Gendongarum Kecamatan Kanor Kabupaten Bojonegoro. Spirit Publik: Jurnal Administrasi Publik, 15(2), 97. https://doi.org/10.20961/sp.v15i2.43501 